\title{
Assessment of left ventricular function: visual or quantitative?
}

\author{
E. E. van der Wall • J. H. C. Reiber
}

Received: 11 October 2010/Accepted: 13 October 2010/Published online: 28 October 2010

(C) The Author(s) 2010. This article is published with open access at Springerlink.com

Assessment of cardiac function continues to be an important issue in patients with assumed left ventricular (LV) dysfunction [1-10]. In particular in patients with enlarged left ventricles, such as occurs in ischemic and idiopathic dilated cardiomyopathy, accurate assessment of LV function remains pivotal [11-14]. To assess myocardial function, different diagnostic methods are currently performed such as echocardiography, single photon emission computed tomography (SPECT), and cardiac magnetic resonance imaging (CMR) [15-23]. In the clinical arena, detection of myocardial function is predominantly based on echocardiographic studies. In addition, nuclear techniques, showing preserved tracer uptake and metabolism in viable myocardium, may also assess left ventricular function and wall motion. Volumetric analysis by gated SPECT imaging offers considerable additional value to SPECT myocardial perfusion imaging in characterizing functional abnormalities thereby potentially improving test specificity [24-37]. Subsequent to echocardiography and gated SPECT imaging, CMR has now long been recognized as an accurate and reliable means of evaluating LV

Editorial comment to the article by Holloway et al. (doi: 10.1007/s10554-010-9706-0).

E. E. van der Wall ( $₫)$ · J. H. C. Reiber Department of Cardiology, Leiden University Medical Center, P.O. Box 9600, Leiden, Netherlands

e-mail: e.e.van_der_wall@lumc.nl function. Considerable progress has been made in the field of CMR, providing accurate evaluation of $\mathrm{LV}$ function parameters in coronary artery disease, heart failure, hypertrophic cardiomyopathy, and many other cardiac diseases [38-49]. CMR may be more accurate than echocardiography and gated SPECT in establishing LV volumetric parameters because of its more objective analysis and superb spatial resolution, respectively [50-58].

In the current issue of the International Journal of Cardiovascular Imaging, Holloway et al. [59] nicely determined the accuracy of visual analysis of LV function in comparison with the accepted quantitative reference standard CMR. Cine CMR imaging was performed at $1.5 \mathrm{~T}$ on 44 patients with a range of $\mathrm{LV}$ ejection fractions (EF) between 5 and $80 \%$. Eighteen clinicians were asked to visually assess LVEF after sequentially being shown cine images of a fourchamber (horizontal long axis), two-chamber (vertical long axis) and a short axis stack. The authors found strong correlations between visual and quantitative assessment. However, LVEF was underestimated in all categories (by $8.4 \%$ for horizontal long axis, $8.4 \%$ for horizontal long axis + vertical long axis and $7.9 \%$ for horizontal long axis + vertical long axis + short axis stack). LVEF was particularly underestimated in patients with mild $\mathrm{LV}$ dysfunction (17.4\%, $P<0.01)$, less for moderate $(4.9 \%)$ and not for severe impairment (1\%). It was concluded that assessing more than one view of the heart improved visual assessment of LVEF. However, the 18 
clinicians underestimated LVEF by $8.4 \%$ on average, with particular inaccuracy for those patients with mild LV dysfunction. Given the important clinical information provided by LV assessment, in particular in deformed left ventricles, the authors recommended quantitative analysis for accurate assessment of LV function.

Several studies have compared visual and quantitative assessment of LVEF, both in normal subjects and patients with impaired LV function [60-68]. Nearly all studies showed that LVEF is underestimated by visual estimation compared with the quantitative assessment. Holman et al. [65], using a dedicated analytical software package (MASS version 1.0) including a modified centerline method and a new 3D-analysis approach, showed in 25 patients after acute myocardial infarction that the use of threedimensional quantitative analysis of cine CMR images accurately quantifies the extent of regional LV dysfunction in the infarcted heart. Van der Geest et al. [66] evaluated a computer algorithm for the automated detection of LV endocardial and epicardial boundaries in time series of short-axis CMR images based on an Active Appearance Motion Mode. In 20 short-axis CMR examinations, manual contours were defined in multiple temporal frames (from enddiastole to end-systole) in multiple slices from base to apex. Global LV function results derived from automatically detected contours were compared with results obtained from manually traced boundaries. Automated contour detection resulted in small, but statistically non-significant, underestimations of LV volumes and mass: and an excellent agreement was observed in the LVEF. The fully automated contour detection method provided assessment of quantitative global LV function that is comparable to manual analysis, but offered the advantage of being more consistent, more reproducible, and less operatordependent. Sievers et al. [67] investigated 100 subjects (40 normal subjects, 40 patients with ischemic cardiomyopathy, and 20 patients with nonischemic cardiomyopathy) using a 1.5-T CMR imager. LVEF was significantly underestimated by the visual reader in all 3 groups. The difference was larger in normal subjects than in patients with cardiomyopathy. The interobserver variability was smaller for the quantitative assessment than for the visual estimation. Attili et al. [69] reported that recent quantitationoriented advances in CMR hardware and software have resulted in significant improvements in image quality and a reduction in imaging time.

To conclude, the study by Holloway et al. [59] confirms that the visual CMR approach for LVEF assessment may be used for rapid assessment of LV function in clinical practice where accuracy is of less concern. For an accurate analysis of LV function, the quantitative standard short axis approach is required.

Open Access This article is distributed under the terms of the Creative Commons Attribution Noncommercial License which permits any noncommercial use, distribution, and reproduction in any medium, provided the original author(s) and source are credited.

\section{References}

1. Bax JJ, van der Wall EE, Harbinson M (2004) Radionuclide techniques for the assessment of myocardial viability and hibernation. Heart 90(Suppl 5):v26-v33

2. Bavelaar-Croon CD, Pauwels EK, van der Wall EE (2001) Gated single-photon emission computed tomographic myocardial imaging: a new tool in clinical cardiology. Am Heart J 14:383-390

3. van der Wall EE, Heidendal GA, den Hollander W, Westera G, Roos JP (1980) I-123 labeled hexadecenoic acid in comparison with Thallium-201 for myocardial imaging in coronary heart disease. A preliminary study. Eur J Nucl Med 5:401-405

4. Slart RH, Bax JJ, Sluiter WJ, van Veldhuisen DJ, Jager PL (2004) Added value of attenuation-corrected Tc-99m tetrofosmin SPECT for the detection of myocardial viability: comparison with FDG SPECT. J Nucl Cardiol 11:689-696

5. Ten Cate FJ (2009) Cardiomyopathies: a revolution in molecular medicine and cardiac imaging. Neth Heart J 17:456-457

6. America YG, Bax JJ, Dibbets-Schneider P, Pauwels EK, Van der Wall EE (2005) Evaluation of the Quantitative Gated SPECT (QGS) software program in the presence of large perfusion defects. Int $\mathrm{J}$ Cardiovasc Imaging 21: 519-529

7. van Eck-Smit BL, van der Wall EE, Kuijper AF, Zwinderman AH, Pauwels EK (1993) Immediate thallium-201 reinjection following stress imaging: a time-saving approach for detection of myocardial viability. J Nucl Med 34:737-743

8. Groutars RG, Verzijlbergen JF, Tiel-van Buul MM et al (2003) The accuracy of 1-day dual-isotope myocardial SPECT in a population with high prevalence of coronary artery disease. Int J Cardiovasc Imaging 19:229-238

9. van der Wall EE, den Hollander W, Heidendal GA, Westera G, Majid PA, Roos JP (1981) Dynamic myocardial scintigraphy with 123I-labeled free fatty acids in patients with myocardial infarction. Eur J Nucl Med 6:383-389

10. Braun S, van der Wall EE, Emanuelsson S, Kobrin I (1996) Effects of a new calcium antagonist, mibefradil (Ro 40-5967), on silent ischemia in patients with stable 
chronic angina pectoris: a multicenter placebo-controlled study. The mibefradil international study group. J Am Coll Cardiol 27:317-322

11. Portegies MC, Schmitt R, Kraaij CJ et al (1991) Lack of negative inotropic effects of the new calcium antagonist Ro 40-5967 in patients with stable angina pectoris. J Cardiovasc Pharmacol 18:746-751

12. de Nooijer R, Verkleij CJ, von der Thüsen JH et al (2006) Lesional overexpression of matrix metalloproteinase-9 promotes intraplaque hemorrhage in advanced lesions but not at earlier stages of atherogenesis. Arterioscler Thromb Vasc Biol 26:340-346

13. Hoogendoorn LI, Pattynama PM, Buis B, van der Geest RJ, van der Wall EE, de Roos A (1995) Noninvasive evaluation of aortocoronary bypass grafts with magnetic resonance flow mapping. Am J Cardiol 75:845-848

14. van der Laarse A, Kerkhof PL, Vermeer F et al (1988) Relation between infarct size and left ventricular performance assessed in patients with first acute myocardial infarction randomized to intracoronary thrombolytic therapy or to conventional treatment. Am J Cardiol 61: $1-7$

15. Bakx AL, van der Wall EE, Braun S, Emanuelsson H, Bruschke AV, Kobrin I (1995) Effects of the new calcium antagonist mibefradil (Ro 40-5967) on exercise duration in patients with chronic stable angina pectoris: a multicenter, placebo-controlled study. Ro 40-5967 International Study Group. Am Heart J 130:748-757

16. van Rugge FP, Boreel JJ, van der Wall EE et al (1991) Cardiac first-pass and myocardial perfusion in normal subjects assessed by sub-second Gd-DTPA enhanced MR imaging. J Comput Assist Tomogr 15:959-965

17. Nijveldt R, Beek AM, Hirsch A et al (2008) 'No-reflow' after acute myocardial infarction: direct visualisation of microvascular obstruction by gadolinium-enhanced CMR. Neth Heart J 16:179-181

18. Bax JJ, Visser FC, van Lingen A, Cornel JH, Fioretti PM, van der Wall EE (1997) Metabolic imaging using F18fluorodeoxyglucose to assess myocardial viability. Int $\mathrm{J}$ Card Imaging 13:145-155

19. Underwood SR, Bax JJ, vom Dahl J et al (2004) Study group of the European society of cardiology. Imaging techniques for the assessment of myocardial hibernation. Report of a study group of the European society of cardiology. Eur Heart J 25:815-836

20. Torn M, Bollen WL, van der Meer FJ, van der Wall EE, Rosendaal FR (2005) Risks of oral anticoagulant therapy with increasing age. Arch Intern Med 165:1527-1532

21. Slart RH, Bax JJ, van Veldhuisen DJ, van der Wall EE, Dierckx RA, Jager PL (2006) Imaging techniques in nuclear cardiology for the assessment of myocardial viability. Int J Cardiovasc Imaging 22:63-80

22. Slart RH, Bax JJ, van Veldhuisen DJ et al (2006) Prediction of functional recovery after revascularization in patients with chronic ischaemic left ventricular dysfunction: head-to-head comparison between 99mTc-sestamibi/ 18F-FDG DISA SPECT and 13N-ammonia/18F-FDG PET. Eur J Nucl Med Mol Imaging 33:716-723

23. Bleeker GB, Holman ER, Steendijk P et al (2006) Cardiac resynchronization therapy in patients with a narrow QRS complex. J Am Coll Cardiol 48:2243-2250
24. Ypenburg C, van der Wall EE, Schalij MJ, Bax JJ (2008) Imaging in cardiac resynchronisation therapy. Neth Heart $\mathbf{J}$ 16:S36-S40

25. Ypenburg C, Westenberg JJ, Bleeker GB et al (2008) Noninvasive imaging in cardiac resynchronization therapy-part 1: selection of patients. Pacing Clin Electrophysiol 31:1475-1499

26. van der Geest RJ, Niezen RA, van der Wall EE, de Roos A, Reiber JH (1998) Automated measurement of volume flow in the ascending aorta using MR velocity maps: evaluation of inter- and intraobserver variability in healthy volunteers. J Comput Assist Tomogr 22:904-911

27. Tops LF, Schalij MJ, Holman ER, van Erven L, van der Wall EE, Bax JJ (2006) Right ventricular pacing can induce ventricular dyssynchrony in patients with atrial fibrillation after atrioventricular node ablation. J Am Coll Cardiol 48:1642-1648

28. Oemrawsingh PV, Mintz GS, Schalij MJ, Zwinderman AH, Jukema JW, van der Wall EE (2003) Intravascular ultrasound guidance improves angiographic and clinical outcome of stent implantation for long coronary artery stenoses: final results of a randomized comparison with angiographic guidance (TULIP Study). Circulation 107:62-67

29. Bleeker GB, Bax JJ, Fung JW et al (2006) Clinical versus echocardiographic parameters to assess response to cardiac resynchronization therapy. Am J Cardiol 97:260-263

30. Bleeker GB, Schalij MJ, Boersma E et al (2007) Relative merits of M-mode echocardiography and tissue Doppler imaging for prediction of response to cardiac resynchronization therapy in patients with heart failure secondary to ischemic or idiopathic dilated cardiomyopathy. Am J Cardiol 99:68-74

31. Ypenburg C, Roes SD, Bleeker GB et al (2007) Effect of total scar burden on contrast-enhanced magnetic resonance imaging on response to cardiac resynchronization therapy. Am J Cardiol 99:657-660

32. Ypenburg C, Schalij MJ, Bleeker GB et al (2006) Extent of viability to predict response to cardiac resynchronization therapy in ischemic heart failure patients. J Nucl Med 47:1565-1570

33. Tops LF, Bax JJ, Zeppenfeld K et al (2005) Fusion of multislice computed tomography imaging with threedimensional electroanatomic mapping to guide radiofrequency catheter ablation procedures. Heart Rhythm 2: 1076-1081

34. Ypenburg C, Schalij MJ, Bleeker GB et al (2007) Impact of viability and scar tissue on response to cardiac resynchronization therapy in ischaemic heart failure patients. Eur Heart J 28:33-41

35. Ypenburg C, Sieders A, Bleeker GB et al (2007) Myocardial contractile reserve predicts improvement in left ventricular function after cardiac resynchronization therapy. Am Heart J 154:1160-1165

36. Molhoek SG, Bax JJ, van Erven L et al (2004) Comparison of benefits from cardiac resynchronization therapy in patients with ischemic cardiomyopathy versus idiopathic dilated cardiomyopathy. Am J Cardiol 93:860-863

37. Tio RA, Slart RH, de Boer RA et al (2009) Reduced regional myocardial perfusion reserve is associated with impaired contractile performance in idiopathic dilated cardiomyopathy. Neth Heart J 17:470-474 
38. van der Wall EE, van Dijkman PR, de Roos A et al (1990) Diagnostic significance of gadolinium-DTPA (diethylenetriamine penta-acetic acid) enhanced magnetic resonance imaging in thrombolytic treatment for acute myocardial infarction: its potential in assessing reperfusion. Br Heart $\mathbf{J}$ 63:12-17

39. Holman ER, van Jonbergen HP, van Dijkman PR, van der Laarse A, de Roos A, van der Wall EE (1993) Comparison of magnetic resonance imaging studies with enzymatic indexes of myocardial necrosis for quantification of myocardial infarct size. Am J Cardiol 71:1036-1040

40. van Rugge FP, Holman ER, van der Wall EE, de Roos A, van der Laarse A, Bruschke AV (1993) Quantitation of global and regional left ventricular function by cine magnetic resonance imaging during dobutamine stress in normal human subjects. Eur Heart J 14:456-463

41. Sciagrà R, Leoncini M (2005) Gated single-photon emission computed tomography. The present-day "one-stopshop" for cardiac imaging. Q J Nucl Med Mol Imaging 49:19-29

42. Pluim BM, Lamb HJ, Kayser HW, Leujes F et al (1998) Functional and metabolic evaluation of the athlete's heart by magnetic resonance imaging and dobutamine stress magnetic resonance spectroscopy. Circulation 97:666-672

43. Pluim BM, Beyerbacht HP, Chin JC et al (1997) Comparison of echocardiography with magnetic resonance imaging in the assessment of the athlete's heart. Eur Heart J 18:1505-1513

44. Pluim BM, Chin JC, De Roos A et al (1996) Cardiac anatomy, function and metabolism in elite cyclists assessed by magnetic resonance imaging and spectroscopy. Eur Heart J 17:1271-1278

45. Kurvers MJ, Braam RL, Verzijlbergen JF, Heestermans AA, Ten Berg JM (2007) Myocardial salvage in STEMI patients treated with primary coronary angioplasty as demonstrated by myocardial SPECT. Neth Heart J 15:422-423

46. Germans T, Nijveldt R, Brouwer WP et al (2010) The role of cardiac magnetic resonance imaging in differentiating the underlying causes of left ventricular hypertrophy. Neth Heart J 18:135-143

47. Groenink M, Lohuis TA, Tijssen JG et al (1999) Survival and complication free survival in Marfan's syndrome: implications of current guidelines. Heart 82:499-504

48. van Dijkman PR, van der Wall EE, de Roos A et al (1991) Acute, subacute, and chronic myocardial infarction: quantitative analysis of gadolinium-enhanced MR images. Radiology 180:147-151

49. van der Wall EE, Vliegen HW, de Roos A, Bruschke AV (1995) Magnetic resonance imaging in coronary artery disease. Circulation 92:2723-2739

50. Vliegen HW, Doornbos J, de Roos A, Jukema JW, Bekedam MA, van der Wall EE (1997) Value of fast gradient echo magnetic resonance angiography as an adjunct to coronary arteriography in detecting and confirming the course of clinically significant coronary artery anomalies. Am J Cardiol 79:773-776

51. Matheijssen NA, Louwerenburg HW, van Rugge FP et al (1996) Comparison of ultrafast dipyridamole magnetic resonance imaging with dipyridamole SestaMIBI SPECT for detection of perfusion abnormalities in patients with one-vessel coronary artery disease: assessment by quantitative model fitting. Magn Reson Med 35:221-228

52. Atsma DE, Bavelaar-Croon CD, Germano G et al (2000) Good correlation between gated single photon emission computed myocardial tomography and contrast ventriculography in the assessment of global and regional left ventricular function. Int J Card Imaging 16:447-453

53. Bavelaar-Croon CD, Kayser HW, van der Wall EE et al (2000) Left ventricular function: correlation of quantitative gated SPECT and MR imaging over a wide range of values. Radiology 217:572-575

54. Wahba FF, Lamb HJ, Bax JJ et al (2001) Assessment of regional myocardial wall motion and thickening by gated 99Tcm-tetrofosmin SPECT: a comparison with magnetic resonance imaging. Nucl Med Commun 22:663-671

55. Bax JJ, Lamb H, Dibbets P, Pelikan H et al (2000) Comparison of gated single-photon emission computed tomography with magnetic resonance imaging for evaluation of left ventricular function in ischemic cardiomyopathy. Am J Cardiol 86:1299-1305

56. Matheijssen NA, Baur LH, Reiber JH et al (1996) Assessment of left ventricular volume and mass by cine magnetic resonance imaging in patients with anterior myocardial infarction intra-observer and inter-observer variability on contour detection. Int $\mathrm{J}$ Card Imaging 12:11-19

57. Persson E, Carlsson M, Palmer J, Pahlm O, Arheden H (2005) Evaluation of left ventricular volumes and ejection fraction by automated gated myocardial SPECT versus cardiovascular magnetic resonance. Clin Physiol Funct Imaging 25:135-141

58. Ioannidis JP, Trikalinos TA, Danias PG (2002) Electrocardiogram-gated single-photon emission computed tomography versus cardiac magnetic resonance imaging for the assessment of left ventricular volumes and ejection fraction: a meta-analysis. J Am Coll Cardiol 39:2059-2068

59. Holloway CJ, Edwards LM, Rider OJ et al. A comparison of visual and quantitative assessment of left ventricular ejection fraction by cardiac magnetic resonance. Int $\mathbf{J}$ Cardiovasc Imaging 2010 Oct 1 [Epub ahead of print]

60. van Rugge FP, van der Wall EE, Bruschke AV (1992) New developments in pharmacologic stress imaging. Am Heart J 124:468-485

61. van Rugge FP, van der Wall EE, van Dijkman PR, Louwerenburg HW, de Roos A, Bruschke AV (1992) Usefulness of ultrafast magnetic resonance imaging in healed myocardial infarction. Am J Cardiol 70:1233-1237

62. van der Geest RJ, de Roos A, van der Wall EE, Reiber JH (1997) Quantitative analysis of cardiovascular MR images. Int J Card Imaging 13:247-258

63. Matheijssen NA, de Roos A, Doornbos J, Reiber JH, Waldman GJ, van der Wall EE (1993) Left ventricular wall motion analysis in patients with acute myocardial infarction using magnetic resonance imaging. Magn Reson Imaging 11:485-492

64. Holman ER, Vliegen HW, van der Geest RJ et al (1995) Quantitative analysis of regional left ventricular function after myocardial infarction in the pig assessed with cine magnetic resonance imaging. Magn Reson Med 34: 161-169 
65. Holman ER, Buller VG, de Roos A et al (1997) Detection and quantification of dysfunctional myocardium by magnetic resonance imaging. A new three-dimensional method for quantitative wall-thickening analysis. Circulation 95: 924-931

66. van der Geest RJ, Lelieveldt BP, Angelié E et al (2004) Evaluation of a new method for automated detection of left ventricular boundaries in time series of magnetic resonance images using an active appearance motion model. J Cardiovasc Magn Reson 6:609-617

67. Sievers B, Kirchberg S, Franken U, Puthenveettil BJ, Bakan A, Trappe HJ (2005) Visual estimation versus quantitative assessment of left ventricular ejection fraction: a comparison by cardiovascular magnetic resonance imaging. Am Heart J 150:737-742

68. van der Wall EE, Bax JJ, Reiber JH. Cardiac magnetic resonance imaging analysis in STEMI: quantitative or still visual? Int J Cardiovasc Imaging. 2010 May 8. [Epub ahead of print]

69. Attili AK, Schuster A, Nagel E, Reiber JH, van der Geest RJ (2010) Quantification in cardiac MRI: advances in image acquisition and processing. Int $\mathrm{J}$ Cardiovasc Imaging 26(Suppl 1):27-40 